\title{
Statyba
}

\section{LOCATION PROBLEMS OF CONCRETE MIX PRODUCTION PLANTS}

\section{Celińska-Myslaw \& O. Kapliński DSc, PhD, Eng.}

To cite this article: M. Celińska-Myslaw \& O. Kapliński DSc, PhD, Eng. (1998) LOCATION PROBLEMS OF CONCRETE MIX PRODUCTION PLANTS, Statyba, 4:4, 292-296, DOI: 10.1080/13921525.1998.10531420

To link to this article: https://doi.org/10.1080/13921525.1998.10531420

曲 Published online: 26 Jul 2012.

Submit your article to this journal

III Article views: 62 


\title{
LOCATION PROBLEMS OF CONCRETE MIX PRODUCTION PLANTS
}

\author{
M. Celińska-Myslaw, O. Kapliński
}

\section{Introduction}

As the market economy expands, some construction industries face problems due to the complexity of the situation and increased competition. Increased technological and economic effectiveness of building production is possible through a rational use of programming and design techniques. A particularly important assignment in the sphere of designing infrastructure for the building industry is the solution of location problems.

Programming and designing of the infrastructure in the construction industry is an important element in preparing its means for production.

Current experiences in construction practices in Poland almost universally demonstrate a lack of recognition of the importance of rational programming and design applications. These phases are among the most decisive ones as far as technological and economic effectiveness in building production under conditions of the market economy is concerned.

This includes the need of solving technologicaltechnical problems as well as organizational and economic concerns, bearing in mind the proper time frame and variability of the demand structure.

The modelling of concrete mix location problems is very important in construction industry and there are many aspects of this problem. Some of them are presented in $[2,6]$. Our approach required an elaboration of the method using the prognoses of demand for concrete mix. Methodology for setting demand quantities of concrete mix is described in [1,2].

This paper presents a mathematical model proposed for solving location problems of concrete mix production sites. Following appropriate modifications,

it may be employed in further questions concerning the infrastructure in the building industry.

\section{Formulating the optimization task of the mathe- matical model}

The general optimization task is as follows: given the presently accepted technological and organizational levels, that the location option, production level, as well as type and number of production facilities for producing concrete mix should be chosen, and the sum of the function of this criterion should reach a maximal amount. For the purposes of solving the question of localizing concrete mix production plants, a mathematical model is developed and presented below. In this formula, the criterion denoting the minimization of costs comprising the individual elements of the production line is designated, ie the supply of raw materials necessary for the production of concrete mix, and its production and transport.

In this mathematical formula, single costs connected with an alternate location are assigned. These, as well as production costs of the concrete mix are described as variable functions in relation to the production amount.

The demand for concrete mix, in the mathematical model, is expressed as the function of the type of building under construction, the state of its completion, as well as the broader aspect of its completion.

Within the context of time horizons, the denoted investment cycle is connected with a lower demand.

The problems, in their generalized mathematical expression, have been presented non-linearly. Further procedures were employed to simplify the problem and to express it in terms of integral numbers.

The mathematical form of the criterion is as follows:

$$
\begin{aligned}
& \sum_{\mathrm{r}=1}^{\mathrm{K}} \sum_{\mathrm{s}=1}^{\mathrm{L}} \sum_{\mathrm{t}=1}^{\mathrm{T}} \mathrm{C}_{\mathrm{rst}} \mathrm{X}_{\mathrm{rst}}+\sum_{\mathrm{r}=1}^{\mathrm{K}} \sum_{\mathrm{s}=1}^{\mathrm{L}} \sum_{\mathrm{i}=1}^{\mathrm{M}} \sum_{\mathrm{t}=1}^{\mathrm{T}} \mathrm{C}_{\mathrm{rsit}} \mathrm{X}_{\mathrm{rsit}}+\sum_{\mathrm{h}=1}^{\mathrm{W}} \sum_{\mathrm{p}=1}^{\mathrm{Z}} \sum_{\mathrm{i}=1}^{\mathrm{M}} \sum_{\mathrm{t}=1}^{\mathrm{T}} \mathrm{f}_{\mathrm{hpit}}\left(\mathrm{X}_{\mathrm{hpit}}\right) \\
& \mathrm{X}_{\text {hpit }}+\sum_{\mathrm{p}=1}^{\mathrm{Z}} \sum_{\mathrm{i}=1}^{\mathrm{M}} \sum_{\mathrm{i}=1}^{\mathrm{N}} \sum_{\mathrm{t}=1}^{\mathrm{T}} \mathrm{C}_{\mathrm{pijt}} \mathrm{X}_{\mathrm{pijt}}+\sum_{\mathrm{h}=1}^{\mathrm{W}} \sum_{\mathrm{i}=1}^{\mathrm{M}} \sum_{\mathrm{t}=1}^{\mathrm{T}} \mathrm{f}_{\mathrm{iht}}\left(\mathrm{Y}_{\mathrm{iht}}\right) \mathrm{Y}_{\text {iht }} \rightarrow \min
\end{aligned}
$$


This model is written in consideration of the following constraints:

1. Condition ensuring an adequate supply of raw materials demanded for h-type concrete mix plants located at sites $\mathrm{i}$ :

$$
\sum_{s=1}^{L} \sum_{r=1}^{K} \sum_{i=1}^{M} \sum_{t=1}^{T} X_{s r i t} \geq \sum_{l=1}^{M} \sum_{s=1}^{L} \sum_{t=1}^{T} b_{i s t}
$$

2. Condition ensuring the availability of raw materials from sites $r$ where they are produced:

$$
\sum_{s=1}^{L} \sum_{r=1}^{K} \sum_{i=1}^{M} \sum_{t=1}^{T} X_{s r i t} \leq \sum_{r=1}^{M} \sum_{s=1}^{L} \sum_{t=1}^{T} X_{r s t}
$$

This condition is assumed due to the fact that raw materials used in concrete mix production are also used in other ways and because they are produced for a number of different regions.

3. Condition limiting the production capacities of raw material $s$ at production site $\mathrm{r}$ :

$$
\sum_{s=1}^{L} \sum_{r=1}^{K} \sum_{t=1}^{T} Z_{l r s t} \leq \sum_{s=1}^{L} \sum_{r=1}^{K} \sum_{t=1}^{T} X_{r s t} \leq \sum_{s=1}^{L} \sum_{r=1}^{K} \sum_{t=1}^{T} Z_{2 r s t}
$$

4. Condition limiting the production capacity of the concrete mix plant:

$$
\begin{aligned}
& \sum_{h=1}^{W} \sum_{p=1}^{Z} \sum_{i=1}^{M} \sum_{t=1}^{T} Z_{1 \text { hpit }} \leq \sum_{h=1}^{W} \sum_{p=1}^{Z} \sum_{i=1}^{M} \sum_{t=1}^{T} X_{h p i t} \leq \\
& \leq \sum_{h=1}^{W} \sum_{p=1}^{Z} \sum_{i=1}^{M} \sum_{t=1}^{T} Z_{2 h p i t}
\end{aligned}
$$

5. Condition ensuring an adequate supply of concrete mix to all demand sites $\mathrm{j}$ :

$$
\begin{gathered}
\sum_{i=1}^{M} \sum_{j=}^{N} \sum_{p=1}^{Z} \sum_{t=1}^{T} X_{i j p t}=\sum_{j=1}^{N} \sum_{p=1}^{Z} \sum_{t=1}^{T} b_{j p t} \\
b_{j p t}=\sum_{j=1}^{n} g\left(A_{j}\right) \\
\sum_{j=1}^{n} g\left(A_{j}\right)=\sum_{j=1}^{n_{1}} g\left(A_{j 1}\right)+\sum_{j 2}^{n} g\left(A_{j 2}\right)
\end{gathered}
$$

$A_{j 1}$ - number of cubic objects (ni),

$A_{j} 2$ - number of non-cubic objects $\left(n-n_{i}\right)$

$g\left(A_{j l} 1 V, s t, t\right)$

It is assumed that the quantity of demand for concrete mix with relation to sites $\mathrm{j}$ is a function of the task which is currently being realised; and, in the case of cubic capacity objects, it is the function of its cubic capacity, state of realization and the time of the project realisation.

6. Condition determining the fulfilment of demand for the production of p-type concrete mix at sites $i$ and realised in the $h$ scenario of production capacity:

$$
\sum_{h=1}^{W} \sum_{p=1}^{Z} \sum_{i=1}^{M} \sum_{t=1}^{T} X_{h p i t} \geq \sum_{i=1}^{M} \sum_{j=1}^{N} \sum_{p=1}^{Z} \sum_{t=1}^{T} X_{i j p t}
$$

This condition has been assumed because, at certain production sites, the mix made there shall be used for the production of prefabricated elements. However, in considering the transportation of mix by means of different vehicles, this condition may be stated thus to avoid inequality:

$$
\sum_{h=1}^{W} \sum_{p=1}^{Z} \sum_{i=1}^{M} \sum_{t=1}^{T} X_{h p i t t}=\sum_{i=1}^{M} \sum_{j=1}^{N} \sum_{p=1}^{Z} \sum_{t=1}^{T} X_{i j p t}
$$

7. Condition requiring that only one type of concrete mix plant is located at a given site:

$$
\sum_{i=1}^{M} \sum_{k=1}^{O} \sum_{t=1}^{T} Y_{h i t}=1 \quad \text { or } 0
$$

8. Condition determining the number of concrete mix plants:

$$
\begin{gathered}
\sum_{\mathrm{l}=1}^{\mathrm{M}} \sum_{\mathrm{k}=1}^{\mathrm{O}} \sum_{\mathrm{t}=1}^{\mathrm{T}} \mathrm{Y}_{\mathrm{hit}}=\mathrm{Z} \\
\mathrm{X}_{\mathrm{xrst}} \geq 0 \\
\mathrm{X}_{\mathrm{rsit}} \geq 0, \\
\mathrm{X}_{\mathrm{hpit}} \geq 0, \\
\mathrm{X}_{\mathrm{ijpt}} \geq 0 .
\end{gathered}
$$

The following notations have been assumed:

$\mathrm{C}_{\text {rst }}$ - unit purchase cost of raw material s from point $\mathrm{r}$ where it is produced in the concrete mix plant $\mathrm{i}$ during time $\mathrm{t}$,

$\mathrm{C}_{\text {sit }}$ - unit transport cost of raw material s from point $r$ where it is produced in the concrete mix plant i during time $t$,

$f_{\text {hpit }}$ - production cost function of type $p$ concrete mix at site $i$ by means of the plant type $h$ during time $\mathrm{t}$, 
$\mathrm{C}_{\mathrm{pijt}}$ - unit transport cost of type p concrete mix from site production $\mathrm{i}$ to demand site $\mathrm{j}$ during time $\mathrm{t}$,

$f_{i h t}\left(Y_{\text {iht }}\right)$ - function of costs resulting from the construction of a type $h$ concrete mix plant at site $i$ during time $\mathrm{t}$,

$\mathrm{X}_{\mathrm{rst}}$ - quantity of raw material s produced at site $r$ in time $t$,

$X_{\text {srit }}$ - quantity of raw material s transported from site $r$ to the concrete mix plant $i$ in time $t$,

$\mathrm{X}_{\text {hpit }}$ - quantity of $\mathrm{p}$ type concrete mix produced at site $\mathrm{i}$ by an $\mathrm{h}$ type plant in time $\mathrm{t}$,

$\mathrm{X}_{\mathrm{pijt}}$ - quantity of $\mathrm{p}$ type concrete mix transported from site $\mathrm{i}$ to demand site $\mathrm{j}$ in time $\mathrm{t}$,

$\mathrm{Y}_{\text {iht }}$ - a decision variable having a value of $0-1$, linked to decisions made about construction site location,

$\mathrm{Z}_{\mathrm{Irst}}$ - the lover limit denoting site $\mathrm{r}$ production capacity, where raw material $\mathrm{s}$ is produced in time $\mathrm{t}$,

$\mathrm{Z}_{2 \text { rst }}$ - top limit denoting site $\mathrm{r}$ production capacity time $\mathrm{t}$,

$\mathrm{Z}_{\text {lhpit }}$ - lover limit line of $\mathrm{p}$ type concrete mix production capacity at site $\mathrm{i}$ by an $\mathrm{h}$ type plant in time $\mathrm{t}$

$\mathrm{Z}_{2 \mathrm{hpit}}$ - top limit line of $\mathrm{p}$ type concrete mix production capacity at site $\mathrm{i}$ by an $\mathrm{h}$ type plant in time $\mathrm{t}$,

$b_{\text {ist }}$ - demand for raw material $s$ in time $t$ from $a$ concrete mix plant located at site $i$,

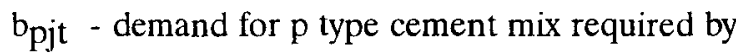
construction site $\mathrm{j}$ in time $t$,

$\mathrm{V}$ - cubic capacity of the building,

st - state of realisation,

$\mathrm{r}$ - raw material production site,

s - raw materials type,

i - location site of concrete mix plants,

p - type of concrete mix produced,

$\mathrm{j}$ - area of demand sites,

$\mathrm{k}$ - type of concrete mix plant feasible at a given site.

\section{The creation of location options}

In optimization procedures, the creation of location options is based upon ordering the location factors to the criterion function and to the constraint conditions. In order to analyze the question of localizing concrete mix production plants, location factors were created on the basis of introduced changes concerning production capacity, the number of concrete mix production facilities, the number of plant location sites, the number of plants, single costs, availability and type of transport facilities for the concrete mix. The level of production capacity of a plant is determined on the basis of an annual practical output of concrete mix, calculated following the consideration of accepted technological and organizational assumptions in production. In order to account for the nonuniformity of demand for concrete mix, the production capacity was lowered by $20 \%$. The accepted production capacity figures allowed for the introduction of a discrete number of concrete mix production plant sites. At the same time, an alternate location was created in which the number of proposed concrete mix plants did not result from the accepted levels of production capacities.

In the creation of subsequent location, changeable location sites were also considered. These considerations were based on the number of sites, where there was already a currently operational concrete mix production plant and new sites being introduced. The basis for alternate location sites was a topographical analysis of the area considered. This was conducted on the method of subdivision presented in papers by B. Kopocinski [3] and L. Szamkolowicz and J. Woznica [5].

The analyzed area was subdivided into squares representing $2 \times 2 \mathrm{~km}$ on a side and tested for their suitability to localizing plants. Location options also considered single costs encountered in the setting up of new plants. These costs were calculated on the basis of alternate location sites. As well, an alternate location entailed possible transport routes connecting raw materials bases, concrete mix production sites and other production sites with areas of demand for concrete mix.

\section{Solved location problems of concrete mix plants}

According to the conditions resulting from the notation of model of concrete mix plant location, calculations were performed by considering sub-problems connected with individual time reference frames by means of the branch and bound method. Calculations were conducted by employing standard discrete programming developed by Lindo-Systems Inc. [4]. Examples of this program's application are presented in the thesis [2] and in the paper [1].

A computational analysis was conducted for determined amounts of demand for concrete mix for 
previously prognosticated construction projects over a period of three years within the area of the Poznań municipality. The demand amounts were presented as prognostic values obtained on the basis of concrete mix demand indices in relation to the volume of the given building. The distances between the location sites of concrete mix production and the demand areas were determined to be the real distances resulting from transport routes. The transport costs of raw materials, the production costs of concrete mix and its transport to demand areas were obtained from the analyses and cost calculation. Variable costs were designated with respect to the practical production capacity of the plant.

The computational analysis was performed while considering 14 location sites of concrete mix and 30 areas of its demand. The demand areas were formed by connecting demand sites for which distances were less than $0.5 \mathrm{~km}$. Single costs connected with the setup of plants, the preparation of access routes, storage areas for ingredients, preparation of a settling tank for sludge and the installation of water and electrical utilities were designated for alternative location sites.

In the optimization procedure, location variants were chosen for which the following conditions were accepted:

minimization of total costs for a given level of maximal practical production capacity of the concrete plant and the given number of production facilities;

minimization of total costs for a given level of concrete mix production capacity during a twoshift cycle of work for a given number of production facilities;

minimization of total costs for a given level of practical production capacity of the concrete mix plant and given number of production facilities;

minimization of total costs for a given level of practical production of the concrete mix production plant during a two-shift cycle of work and a given number of production facilities.

Three types of facilities producing concrete mix were considered as well as 14 location sites for concrete mix production plants, 5 alternative location sites, 4 sites for the production of aggregate, 3 sites for the production of cement. The optimal location sites of concrete mix production plants were described, together with the way the production was divided, the means by which various demand areas for concrete mix were connected with the supply areas. The results obtained are presented in $[1,2]$.

\section{Conclusions}

1. The search for location sites for concrete mix production plants were conducted on the basis of a topographical analysis of the terrain. Such an approach may be employed in the solution of other location problems. The consideration of topographic conditions allows for a choice of possible location sites for plants, whereas the description of optimal sites is conducted by means of an optimization balance reckoning.

2. The proposed mathematical model for the question of localizing concrete mix production plants considers, in its mathematical form, the relationship between the amount of concrete mix built into a given structure, the volume of the building and the state of its completion. The proposed relationship is based on demand indices for concrete mix as described for given structures.

3. The conducted mathematical procedure allowed for a description of the optimal location sites for concrete mix production plants in the Poznań municipality at given levels of production output and amounts of demand. Due to the variable nature of investment in construction, there is a continued demand for further practical application of the proposed computational procedure.

\section{Acknowledgements}

The authors wish to thank the Poznan University of Technology for providing research grant (DS 11215/97 and BW 11-215/97) to support this work.

\section{References}

1. M. Celińska-Myslaw, O. Kaplinski. The application of the Lindo program to solving location problems for concrete mix production plants // Statyba, 1998, Vol IV, No 1, p. 56-63.

2. M. Celińska-Myslaw. Programming of concrete-mix plant location with regard to proposed method of demand dimension determination. PhD Thesis / Poznań University of Technology. Poznań, 1990 (in Polish).

3. B. Kopociński. About territorial division of Poland for sectors // Appl. Math. Vol V, 1961 (in Polish).

4. LINDO linear, interactive and discrete optimizer, Lindo System Inc. Chicago, 1984.

5. L. Szamkolowicz and J. Woznica. $\mathrm{Zu}$ dynamischen Problemen der Standortbestimmung von zentralen Be- 
tonwerken // Proc. X IKM Congress, Weimar, 1984, Vol 4, p. 94-96.

6. A. Warszawski. Multidimensional location problems // Operations Research Quarterly, Vol 20, No 1, 1974, p. $165-179$.

Iteikta 19980120

\section{BETONO MIŠINIO GAMYBOS MAZGU IŠDĖSTYMO VIETOVĖJE PROBLEMỤ SPRENDIMAS}

\section{Celińska-Myslaw, O. Kapliński}

\section{S a n tra u a}

Pateikiamas matematinis betono mišinio gamybos mazgu išdestymo vietoveje parinkimo modelis. Sprendžiamas toks optimizacinis uždavinys: maksimalaus efektyvumosiekiama ivertinus turimus technologinius resursus ir organizacines galimybes. Modelyje nagrinejamas medžiagu tiekimas betono mišinio gamybai, mišinio gamyba bei transportavimas; betono mišinio gamybos kainos priklausomybè nuo gamybos apimčiu bei vietoves; betono mišinio paklausa modelyje išreiškiama funkcine priklausomybe tarp statomy pastaty tipu ir jų užbaigtumo laipsnio ir kt. Skaičiuota naudojantis standartine programa, sukurta "Lindo-Systems Inc" [4]. Programos pritaikymas pateiktas šaltiniuose [1,2], kuriuose tyrimo metodika iliustruojama Poznanes (Lenkija) savivaldybès pavyzdžiais.

Esant kintamoms investicijų $\mathfrak{i}$ statybą apimtims yra poreikis ir toliau tobulinti straipsnyje pasiūlytos skaičiavimo metodikos praktini pritaikymą.

Maria CELIŃSKA-MYSLAW. Doctor, Adjunct. Poznań University of Technology. Department of Construction Engineering and Management. 60-965 Poznań, Poland.

$\mathrm{PhD}$ (1990). Research interests: construction engineering, cost calculation, control of production processes.

Oleg KAPLINSKI. Professor, DSc, $\mathrm{PhD}$, Eng. Director of the Institute of Structural Engineering, Head of the Department of Construction Engineering and Management. Poznań University of Technology, 60-965 Poznań, Poland.

Author of 120 articles and books. Member of Ukrainian Building Academy. Research interests: organization and modelling of construction processes. 